\title{
INACTIVATION AND UNSTABILIZATION OF THE TRANSFORMING PRINCIPLE BY MUTAGENIC AGENTS ${ }^{1}$
}

\author{
STEPHEN ZAMENHOF, GRACE LEIDY, EROS HAHN, AND HATTIE E. ALEXANDER \\ Department of Biochemistry and Department of Pediatrics, College of Physicians and Surgeons, \\ Columbia University, New York, New York
}

Received for publication, November 3, 1955

In the previous communication (Zamenhof et $a l ., 1953)$ the study of the inactivation of the transforming principle (deoxyribonucleic acid [DNA] having transforming activity) by several physical and chemical agents has been reported. Some of those agents, especially $\mathrm{Fe}^{++}$, are known to be potent mutagens; others such as temperature oscillation are reported to be weak mutagens, but they have not been tested on the living cell under drastic conditions, such as heating above $76 \mathrm{C}$, available for the study of the transforming principle in vitro. Mutagenic action by other agents such as $\mathrm{DNAase}$ and $\mathrm{HNO}_{2}$ has not been observed but it is doubtful whether these agents, when applied to the living cell, can ever reach its DNA.

The object of the present work is a more detailed study of the effect of mutagenic agents on the transforming principle. The interest in such a study stems from the recognized role of the DNA, or transforming principle, as a heredity determinant. Even though there is still no proof that the DNA is the sole heredity determinant of all the hereditary characters of the cell, there seems to be little doubt that some of the mutable hereditary characters are determined by this substance (Zamenhof, 1955). For such characters one can investigate the possibility that the mutagenic agents act indeed by affecting directly or indirectly the molecules of DNA determining the mutable character.

1 This investigation was supported by research grants E15 (C7), E124 (C4) and C-1760 from the National Institutes of Health, Public Health Service, G-8 from the American Cancer Society upon recommendation of the Committee on Growth of the National Research Council, and by an Institutional Grant from the American Cancer Society to Columbia University. Abstracts of certain parts of this investigation have been presented previously (Zamenhof, 1954; Zamenhof, Leidy and Reiner, 1954; Zamenhof, Leidy and Hahn, 1954).

\section{MATERIALS AND METHODS}

It is to be emphasized that the results reported in this paper refer to the particular biological system used.

Receptor strain used for transformation. The receptor strain used in this study was the $\mathbf{R}_{\mathbf{d}}$ strain (rough) of Haemophilus influenzae as described previously (Zamenhof et al., 1953).

Donor strains used for preparation of the transforming principle. The two capsulated donor strains of type b of Haemophilus influenzae used in this study were the same as in the previous work (Zamenhof et al., 1953). The typical preparation had an activity of 5000 UTA (units of transforming activity, Zamenhof et al., 1953) per $\mu \mathrm{g}$ DNA. The formation of the capsule type b (polyribophosphate) was used as the genetic marker in all experiments except for the study of the effect of $\mathrm{Mn}^{++}$: in this experiment, two genetic markers, type $b$ and streptomycin resistance were used.

Method for testing the activity of the transforming principle, purification of the DNA having transforming activity, analysis of the DNA preparations and the determination of viscosity were the same as described by Zamenhof et al. (1953).

\section{EXPERIMENTAL RESULTS}

Ultraviolet irradiation. Portions $\left(0.6 \mathrm{~cm}^{2}\right)$ of a purified solution of transforming principle in standard buffer (Zamenhof et al., 1953) containing $227 \mu \mathrm{g} \mathrm{DNA} / \mathrm{cm}^{3}$, unless otherwise specified, were subjected to ultraviolet irradiation in an open shallow glass dish $29 \mathrm{~mm}$ in diameter; the dish was mounted on a vibrator for constant agitation. The source of radiation was an 8-watt General Electric Germicidal Lamp G-8 T-5 having its maximum output at 2537 A. The lamp, provided with a reflector (Raymaster, George W. Gates and Co.) was mounted at a distance of $75 \mathrm{~cm}$, unless otherwise stated, from the liquid surface in the dish, and 
at this distance yielded 6.7 to $6.9 \mathrm{ergs} / \mathrm{sec} \mathrm{mm}^{2}$, as measured by a General Electric "Germicidal Ultraviolet Intensity Meter (Haynes)." Immediately after irradiation the samples were tested for activity and viscosity. The resulting activities are represented in figure 1.

It will be seen that the transforming activity is very sensitive to the ultraviolet irradiation; the inactivating doses are of the same order of magnitude as the doses inactivating bacterial viruses (Luria, 1953).

The results (figure 1) suggest a "multi-hit" inactivation; this subject will be discussed further in connection with the unstable transforming principle. The highest dose used in this experiment still failed to produce any change in the viscosity of the preparation. To study the decrease in viscosity, the preparation was irradiated at distances of 8 and $4 \mathrm{~cm}$ for a longer period of time. A dose of $2 \times 10^{5} \mathrm{ergs} / \mathrm{mm}^{2}$ was

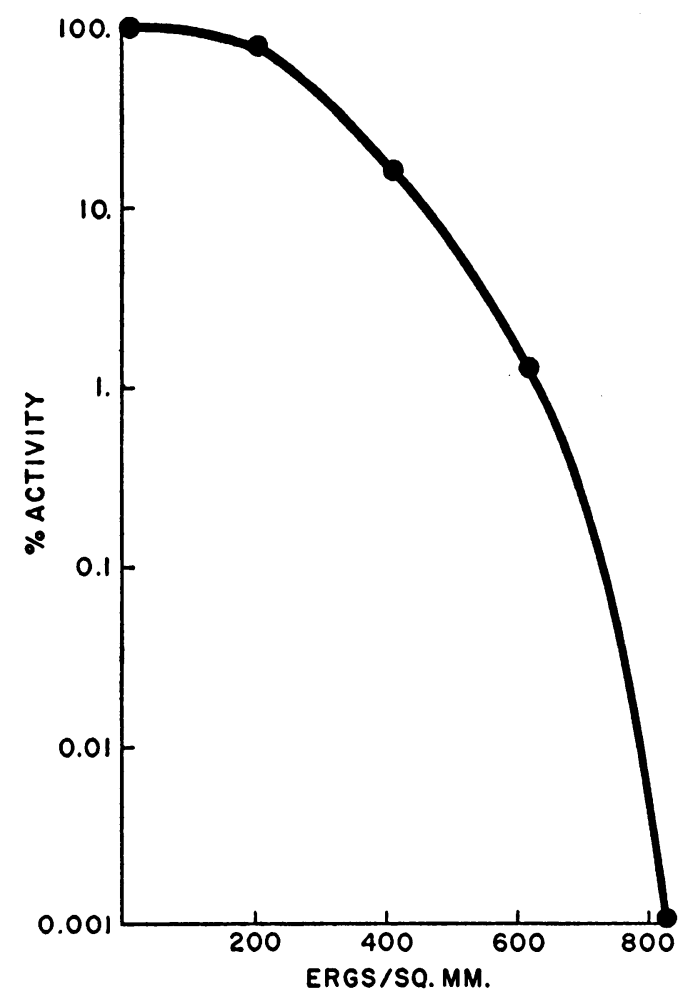

Figure 1. Inactivation of the transforming principle by ultraviolet irradiation. The ordinate indicates the remaining transforming activity as percentage of original activity in logarithmic scale; the abscissa indicates the ultraviolet dose. DNA concentration $227 \mu \mathrm{g} / \mathrm{cm}^{2}$.
TABLE 1

Effect of DNA concentration on inactivation of the transforming principle by ultraviolet irradiation

\begin{tabular}{c|c|c}
\hline DNA & Ultraviolet Dose & $\begin{array}{c}\text { Activity, Per cent of } \\
\text { Original }\end{array}$ \\
\hline$\mu g / \mathrm{cm}^{2}$ & $\mathrm{ergs} / \mathrm{mm}^{2}$ & \\
$27-680$ & 0 & 100 \\
27 & 412 & 0.1 \\
136 & 412 & 2 \\
136 & 618 & 0.1 \\
680 & 618 & 4 \\
\hline
\end{tabular}

necessary to produce the first noticeable drop (3 per cent) of viscosity. This dose is about 500 times higher than the one producing a 10-fold decrease in activity (figure 1). This finding suggests that the changes in the DNA molecule in the cell at the level of mutating or inactivating dose of ultraviolet are much subtler and perhaps of different nature from those studied extensively with the use of viscosity drop as the sole criterion (Davison et al., 1954). ${ }^{2}$

Inasmuch as the DNA solution absorbs the ultraviolet, the dose inactivating the transforming principle in vitro can be expected to depend on the concentration of DNA. To study this effect, solutions of various concentrations of the transforming principle were subjected to irradiation as described before. Table 1 shows that the inactivation strongly depends on the concentration of DNA; this situation should always be taken into account when reporting data on ultraviolet irradiation of DNA.

Irradiation with visible light. Koffler and Markert (1951) reported reduction of viscosity of DNA upon irradiation with visible light in the presence of dyes.

To investigate the effect of visible light on the transforming principle, a $0.6-\mathrm{cm}^{3}$ portion of the solution of transforming principle in standard buffer, containing $146 \mu \mathrm{g} / \mathrm{cm}^{3} \mathrm{DNA}$ and $10 \mu \mathrm{g} /$ $\mathrm{cm}^{3}$ acriflavine (a dye found to be harmless for the transforming principle (Zamenhof et al., 1953)), was irradiated at a distance of $1.5 \mathrm{~cm}$

2 Some of the values of the DNA-depolymerizing dose as recorded in the literature appear to be lower than those reported in this study. This may be due to the previous injury to DNA during its preparation. The lower resistance of injured DNA has been reported previously (Zamenhof, Griboff and Marullo, 1954). 
from a 150-watt tungsten lamp; both the solution (in a test tube) and the lamp were immersed in a constant temperature bath of $23 \mathrm{C}$. No decrease of transforming activity could be observed after irradiation for $1 \mathrm{hr}$. It is concluded that the effect of visible light on the transforming activity, even in the presence of the dye, is insignificant.

Photoreactivation study. To test whether the ultraviolet inactivated transforming principle can be reactivated by visible light (Kelner, 1949), samples partially inactivated by doses of 615 and $820 \mathrm{ergs} / \mathrm{mm}^{2}$ (figure 1) were subjected in the same dish to irradiation for $11 / 2 \mathrm{hr}$ at $30 \mathrm{C}$ from a long-wave ultraviolet lamp (H-5 General Electric), filtered to give a band peak at $3650 \mathrm{~A}$. The lamp was placed $30 \mathrm{~cm}$ from the dish; a $2.5-\mathrm{cm}$ thick layer of $0.5 \mathrm{M} \mathrm{CuCl}_{2}$ solution was placed between the lamp and the plate, to minimize. the heat. These conditions were found to photoreactivate the ultraviolet inactivated Tl-phage when adsorbed to the cells of Escherichia coli strain B (Hill and Rossi, 1952)3. No definite evidence of reactivation of the transforming principle could be obtained. It is concluded that either the ultraviolet inactivation of the transforming principle is an irreversible process different from the ultraviolet irradiation of phage or the cellular system necessary for reactivation is different from the in vitro conditions used in this experiment.

Nitrogen mustards. The mutagenic action of mustards has been discovered by Auerbach and Robson (1946) and extensively corroborated by others.

Herriott (1948) studied inactivation of pneumococcal transforming principle by di(2-chloroethyl)sulfide (sulfur mustard; mustard gas). This mustard in concentrations as low as $6 \times 10^{-5} \mathrm{M}$ was able to cause complete inactivation in $2 \mathrm{hrs}$.

In the present work the action of various nitrogen mustards on transforming principle of $H$. influenzae was studied quantitatively.

To $0.1-\mathrm{cm}^{3}$ portions of purified solutions of transforming principle in $0.1 \mathrm{M}$ sodium citrate buffer ( $\mathrm{pH}$ 7.6) containing $1 \mathrm{mg} \mathrm{DNA} / \mathrm{cm}^{3}$ were added $0.4 \mathrm{~cm}^{3}$ portions of solutions containing various nitrogen mustards in the same buffer. The solutions were incubated at $23 \mathrm{C}$ for $6 \mathrm{hr}$

3 The authors are indebted to Dr. Ruth F. Hill, College of Physicians and Surgeons, Columbia University, New York, for advice in this experiment.

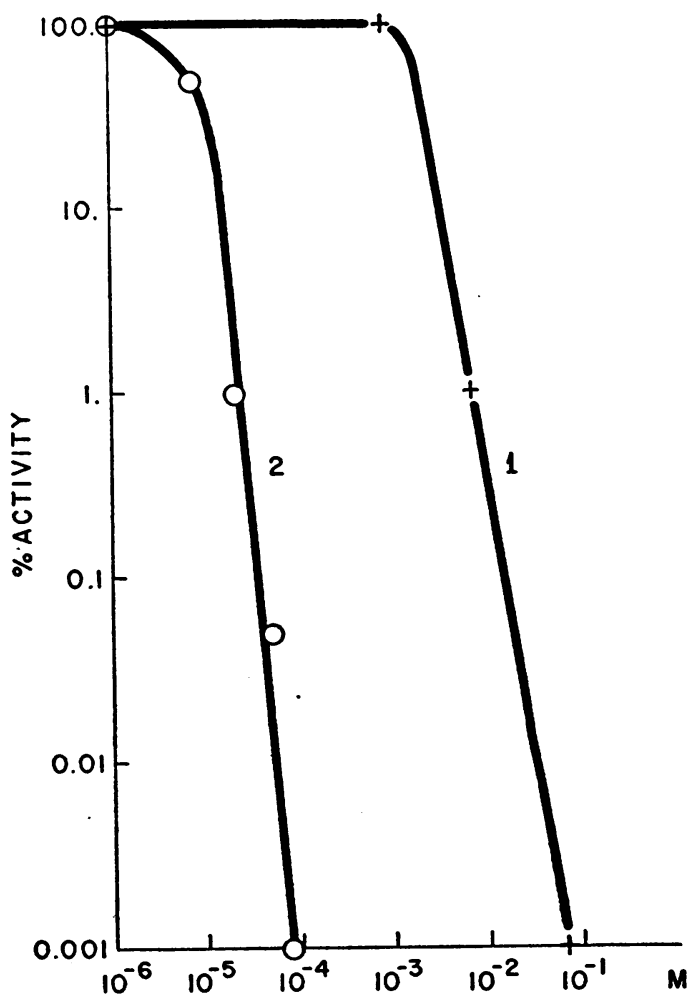

Figure 2. Inactivation of the transforming principle by nitrogen mustards $\mathrm{HN}_{1}$ (curve 1, + ) and $\mathrm{HN}_{2}$ (curve 2,0 ) in $6 \mathrm{hr}$ at $23 \mathrm{C}$. The ordinate as on figure 1 ; the abscissa indicates the concentration of mustards in logarithmic scale. DNA concentration $200 \mu \mathrm{g} / \mathrm{cm}^{8}$.

with gentle vibration and the change of viscosity, if any, determined. To the solutions were then added 2 volumes of absolute ethanol, the resulting fibers removed by centrifugation, washed with ten $3-\mathrm{cm}^{3}$ portions of aqueous 75 per cent ethanol, drained, redissolved in $0.5-\mathrm{cm}^{3}$ portions of standard buffer and tested for transforming activity. Results on figure 2 (curve 2 ) and in table 2 show that di(2-chloroethyl)-methylamine $\left(\mathrm{HN}_{2}\right)^{4}$ causes a complete inactivation at a concentration of $10^{-4} \mathrm{M}$. Ninety per cent loss of activity is observed at a mustard concentration of $2 \times 10^{-6} \mathrm{M} ; \mathrm{a}$ concentration 300 times higher was necessary to produce the first noticeable drop (4 per cent) of viscosity.

The 2-choroethyl diethylamine $\left(\mathrm{HN}_{1}\right)^{4}$ (curve 1, figure 2) has much less inactivating effect than

4 Kindly supplied by Merck and Co., Inc., Rahway, N. J. 
TABLE 2

Comparison of inactivation of the transforming principle by various nitrogen mustards at concentration $10^{-4} \mathrm{M}$. Exposure for 6 hours at $28 C$. DNA $200 \mu \mathrm{g} / \mathrm{cm}^{3}$

\begin{tabular}{|c|c|c|c|}
\hline \multirow{2}{*}{ Designation } & \multicolumn{2}{|c|}{ Substituents } & \multirow{2}{*}{$\begin{array}{l}\text { Activity of Original } \\
\text { Per Cent }\end{array}$} \\
\hline & $\mathbf{R}$ & $\mathbf{R}^{\prime}$ & \\
\hline Control & 一 & - & 100 \\
\hline $\mathrm{HN}_{1}$ & $\mathrm{CH}_{3} \mathrm{CH}_{2}$ & $\mathrm{CH}_{2} \mathrm{CH}_{3}$ & 100 \\
\hline CB1332 & $\mathrm{ClCH}_{2} \mathrm{CH}_{2}$ & $\mathrm{p}-\mathrm{C}_{6} \mathrm{H}_{4} \mathrm{CH}_{2} \mathrm{CH}_{2} \mathrm{COOH}$ & $5-10$ \\
\hline CB1348 & $\mathrm{ClCH}_{2} \mathrm{CH}_{2}$ & p- $\mathrm{C}_{6} \mathrm{H}_{4} \mathrm{CH}_{2} \mathrm{CH}_{2} \mathrm{CH}_{2} \mathrm{COOH}$ & 2 \\
\hline CB3007 & $\mathrm{ClCH}_{2} \mathrm{CH}_{2}$ & $\mathrm{p}-\mathrm{C}_{6} \mathrm{H}_{4} \mathrm{CH}_{2} \mathrm{CHCOOH}^{*}$ & $0.01-0.1$ \\
\hline $\mathbf{H N}_{2}$ & $\mathrm{ClCH}_{2} \mathrm{CH}_{2}$ & $\mathrm{CH}_{3}$ & 0.001 \\
\hline
\end{tabular}

$* \mathrm{DL}$

General mustard formula $\mathrm{ClCH}_{2} \mathrm{CH}_{2}-\mathrm{N}-\mathbf{R}^{\prime}$

$\mathrm{HN}_{2}$. Also, a concentration of $\mathrm{HN}_{1} 300$ times higher than that of $\mathrm{HN}_{2}$ was required to produce a comparable 4 per cent drop of viscosity. One explanation of this lower activity of monofunctional mustards towards DNA is based on the inability of the molecule of any such mustard to react with two nucleotides (Alexander, 1952).

Table 2 presents a comparison of the inactivating power towards transforming principle of $\mathrm{HN}_{2}, \mathrm{HN}_{1}$ and various aromatic nitrogen mustards 5 , all at concentrations of $10^{-4} \mathrm{M}$. The aromatic compounds in this table are arranged in order of increasing power against Walker Carcinoma (Brit. Empire Cancer Campaign, 1952; Ross, 1954). It will be seen that this order corresponds also with the increasing power of inactivation of the transforming principle. These differences cannot be predicted from the structures of the compounds. They also cannot be predicted from the DNA-depolymerizing power of these compounds. When tested in concentration $3 \times 10^{-2} \mathrm{M}$, the mustards no. CB-1332 and CB-1348 had approximately the same depolymerizing power whereas no. CB-3007 had a 13-times lower depolymerizing power. The good agreement of the two orders of biological phenomena, against malignant cells and against the transforming principle, unlikely to be obtained by mere accident, suggests, but by no means proves, that the carcinostatic action of these compounds may occur through the inactivation

sindly supplied by Dr. F. Bergel, The Chester Beatty Research Institute, London. of cellular DNA. However, a correlation between carcinostatic and DNA-inactivating power cannot be automatically assumed in every case. As will be shown further on, the majority of compounds exhibiting carcinostatic activity have no DNA-inactivating power. Even within a group of compounds such as mustards which do inactivate DNA, the correlation need not always exist. The two optical isomers $p$-di(2-chloroethyl) amino-L-phenylalanine and $p$-di(2-chloroethyl) amino-D-phenylalanine and their racemic mixture differ considerably in their activity against Walker Carcinoma 256, the I-form showing intense tumor inhibition, the D-form only slight inhibition and the DL-form an intermediate degree (Bergel and Stock, 1953). When these compounds ${ }^{5}$ were tested for their activity against the transforming principle, no difference between them could be found. This suggests that factors other than the reactivity with DNA could account for the lower carcinostatic activity of the D-form: the latter could be, for instance, subjected to easier destruction in the tissue (Bergel and Stock, 1953).

The nature of the reactions of mustards with DNA has been the subject of a number of studies (Philips, 1950; Ross, 1953). The extent of alkylation of nitrogenous bases by $\mathrm{HN}_{1}$ mustard in the condition of total inactivation of the transforming principle has been studied (Reiner and Zamenhof, unpublished data); it was less than 0.5 per cent of each base. For this reason it is not very useful to discuss stoichiometric relationships 
TABLE 3

Effects of alkylating agents on transforming activity . Exposure for 6 hours at $23 C$. DNA $200 \mu \mathrm{g} / \mathrm{cm}^{3}$

\begin{tabular}{c|r|r|r|r|rr}
\hline \multirow{2}{*}{ Agent } & \multicolumn{5}{|c}{ Activity, Per Cent of Original } \\
\cline { 2 - 5 } & \multicolumn{5}{|c}{ Molarity of agent: } \\
\hline & 0 & $10^{-4}$ & $10^{-3}$ & $10^{-3}$ & $3 \times 10^{-2}$ & $10^{-1}$ \\
\hline Dimethyl sulfate. & 100 & 20 & 0.1 & 0 & 0 & 0 \\
Diethyl sulfate... & 100 & 100 & 100 & 50 & 0 & 0 \\
Methyl iodide. ... & 100 & 100 & 100 & 50 & 10 & 0 \\
$\beta$-Propiolactone... & 100 & 100 & 10 & 0 & 0 & 0 \\
\hline
\end{tabular}

between various reagents and the DNA; the concentration of the latter, computed as nucleotide, is of the order of $5 \times 10^{-4} \mathrm{M}$.

Other alkylating agents. The mutagenic action of dimethyl sulfate and $\beta$-propiolactone has been reported (Rapoport, 1947; Loveless, 1951; Demerec et al., 1951; Kolmark, 1953). It has been shown that the reaction between $\beta$-propiolactone and aromatic amines goes almost exclusively in the direction of alkylation and not of amide formation (Gresham et al., 1951).

In the present work dimethyl sulfate, diethyl sulfate, methyl iodide, and $\beta$-propiolactone have been tested for their ability to inactivate the transforming principle. The experimental arrangement was similar to that described for nitrogen mustards. Results in table 3 show that these alkylating agents strongly inactivate the transforming principle. In general, they are in this respect comparable to the monofunctional nitrogen mustard $\left(\mathrm{HN}_{\mathrm{1}}\right)$; methyl sulfate, which is known to be more reactive than ethyl sulfate, is also a strong inactivating agent.

The above agents as well as the mustards have been presented here as agents which presumably alkylate the amino groups of nitrogenous bases. It must, however, be pointed out that even in these mild conditions they may also react with phosphate, or, less probably, with enolic hydroxyl groups.

Triethyl phosphate tested in concentration $0.1 \mathrm{~m}$ proved to be too weak an alkylating agent in these conditions to cause any inactivation of the transforming principle.

Self-oxidizing agents. The effect of ferrous ion has been reported in the previous publication (Zamenhof et al., 1953).

Ascorbic acid and other self-oxidizing agents have been reported to inactivate, reversibly, the transforming principle of Diplococcus pneu- moniae (McCarty, 1945) and, in higher concentrations, to depolymerize DNA (Limperos and Mosher, 1950). Ascorbic acid is an ubiquitous substance and although its presence in the nucleus in amounts sufficient for detection is doubtful (Tonutti, 1938; Brachet, 1939), it is likely to be present in trace amounts sufficient to exert some action on DNA. Ascorbic acid has also been reported to be a mutagen (Clark, 1953) and might well be one of the causes of "spontaneous" mutations. In view of the correlation between mutagenic agents and agents inactivating the transforming principle postulated in the present work, the inactivation of the transforming principle of $H$. influenzae by ascorbic acid and glutathione was studied.

To $0.3-\mathrm{cm}^{3}$ portions of purified solution of transforming principle in $0.1 \mathrm{M}$ sodium citrate buffer ( $\mathrm{pH}$ 7.6) containing $1 \mathrm{mg} \mathrm{DNA} / \mathrm{cm}^{3}$ were added $1.2-\mathrm{cm}^{3}$ portions of freshly prepared solutions of commercial ascorbic acid or glutathione in the same buffer, or just buffer in the control. The solutions were incubated at $37 \mathrm{C}$ for $1 \mathrm{hr} ; 2$ volumes of absolute ethanol were then added, the resulting fibers removed by centrifugation, washed with ten $5-\mathrm{cm}^{3}$ portions of aqueous 75 per cent ethanol, drained and redissolved in $0.8 \mathrm{~cm}^{3}$ of the same buffer. The solution was then divided into two portions: to one 0.3$\mathrm{cm}^{3}$ portion was added $0.15 \mathrm{~cm}^{3}$ of the same buffer. In the case of ascorbic acid treatment, $0.25 \mathrm{~cm}^{3}$ of $0.06 \mathrm{M}$ glutathione solution in citrate buffer was added to another $0.5-\mathrm{cm}^{3}$ portion to investigate reactivation (McCarty, 1945). Both

TABLE 4

Effect of ascorbic acid and glutathione on transforming activity

\begin{tabular}{c|c|c}
\multicolumn{2}{c|}{ Concentration of Agent } & $\begin{array}{c}\text { Activity, } \\
\text { Per Cent of } \\
\text { Original }\end{array}$ \\
$\begin{array}{c}\text { First treatment } \\
\text { (ascorbic acid) }\end{array}$ & $\begin{array}{c}\text { Second treatment } \\
\text { (glutathione) }\end{array}$ & \\
\cline { 1 - 2 } 0 & 0 & 100 \\
0 & $2 \times 10^{-2} \mathrm{M}$ & 100 \\
$3 \times 10^{-6} \mathrm{M}$ & 0 & 100 \\
$10^{-4} \mathrm{M}$ & 0 & 50 \\
$10^{-4} \mathrm{M}$ & $2 \times 10^{-2} \mathrm{M}$ & 50 \\
$3 \times 10^{-4} \mathrm{M}$ & 0 & 10 \\
$3 \times 10^{-4} \mathrm{M}$ & $2 \times 10^{-2} \mathrm{M}$ & 5 \\
$10^{-3} \mathrm{M}$ & 0 & 0 \\
$10^{-3} \mathrm{M}$ & $2 \times 10^{-2} \mathrm{M}$ & 0 \\
$10^{-2} \mathrm{M}$ & 0 & 0 \\
$10^{-2} \mathrm{M}$ & $2 \times 10^{-2} \mathrm{M}$ & 0 \\
\hline
\end{tabular}


portions were incubated $1 \mathrm{hr}$ at $37 \mathrm{C}$ and tested for transforming activity. Results in table 4 show that ascorbic acid indeed strongly inactivates the transforming principle even at ascorbic acid concentrations lower than $10^{-3} \mathrm{M}$. This compound acts probably as a self-oxidizing agent rather than as a reductant for other substances: glutathione had no effect on the activity of the transforming principle. The mechanism of action of ascorbic acid may involve free radicals and may be similar to that suggested for $\mathrm{Fe}^{++}$ (Zamenhof et al., 1953). A reactivation by glutathione of the transforming principle inactivated by ascorbic acid could not be demonstrated (table 4).

Substances of unknown action. It has been reported that 1,5-diaminobiuret

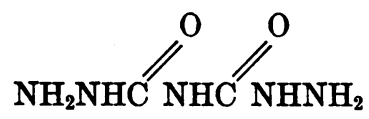

has mutagenic (Hemmerly, 1954) and carcinostatic (Cancer Chemotherapy, 1953) activity. This agent was tested for inactivation of the transforming principle in conditions similar to those described for nitrogen mustard. The $4 \times$ $10^{-2} \mathrm{M}$ concentration of 1,5-diaminobiuret was found sufficient to cause complete inactivation; $4 \times 10^{-4}$ M concentration caused 90 per cent inactivation. It is interesting to note that substances of similar structure: urea, biuret and semicarbazide have no inactivating effect on the transforming principle even when tested in concentrations as high as $4 \mathrm{M}$ urea or $0.2 \mathrm{M}$ biuret and semicarbazide. The chemical basis of this selective activity of diaminobiuret is still unknown.

Di-methylsulfonate of 1,4-dihydroxy-2-butyne ${ }^{5}$ $\mathrm{H}_{3} \mathrm{CSO}_{2} \mathrm{OCH}_{2} \mathrm{C} \equiv \mathrm{CCH}_{2} \mathrm{OSO}_{2} \mathrm{CH}_{3}$

was tested for its ability to inactivate the transforming principle. The substance is sparingly soluble in water or citrate buffer. A 6-hr-old $23 \mathrm{C}$ saturated solution $\left(<2 \times 10^{-4} \mathrm{M}\right)$, tested under the conditions similar to those described for nitrogen mustard, caused complete ( $>10^{5}$-fold) inactivation of the transforming principle. However, a freshly prepared saturated solution, (solid-free supernatant), had no effect on the transforming principle. The chemical basis of this behavior is unknown; the presence of a potent impurity cannot yet be excluded. Several other substituted acetylenes, methyl butynol, methyl pentynol, dimethyl hexynediol and dimethyl octynediol ${ }^{6}$ tested in concentration $0.1 \mathrm{~m}$ had no effect on the activity of the transforming principle. The di-methylsulfonates of ethylene glycol (0.02 $\mathrm{M}$ ) and of 1,4-dihydroxybutane $^{5}$ (saturated solution, approximately $2 \times$ $10^{-4} \mathrm{M}$; also $0.2 \mathrm{~cm}^{3}$ of $0.02 \mathrm{M}$ chloroform solution, emulsified in $0.5 \mathrm{~cm}^{3}$ of the solution of transforming principle as specified above) had no effect on the activity of the transforming principle.

Non-inactivating agents. From the above studies it appears that all reported strong mutagenic agents are also strong inactivators of the transforming principle. Manganous ion, a strong mutagen in $E$. coli (Demerec, 1951) seems to be an exception. When tested in concentrations $0.04 \mathrm{M}, 0.2 \mathrm{M}, 0.4 \mathrm{M}$ and $1.0 \mathrm{M}$ (other conditions similar to those used for nitrogen mustard) it caused no inactivation of the principle transforming to capsule (b) or to streptomycin resistance.

It is to be noted that although $\mathrm{Mn}^{++}$is a strong mutagen in $E$. coli, it seems to be a much weaker mutagen in Salmonella; the mutation rate of one strain of Salmonella is even reported to be completely unaffected by $\mathrm{Mn}^{++}$though susceptible to the effects of other mutagenic agents (Demerec et al., 1954). It thus appears probable that $\mathrm{Mn}^{++}$which, in contradiction to $\mathrm{Fe}^{++}$, is not a demonstrably self-oxidizing ion, is one of the facultative mutagens for some organisms or some genes only and exerts its action through a mechanism other than a direct reaction with DNA. This may also be true for some reported weak mutagens. Obviously, more work is needed on this subject. In particular, the mutagens mentioned in this work should be tested for mutagenicity in $H$. influenzae.

The strong inactivating power of ultraviolet irradiation and nitrogen mustards, reported to have carcinogenic action, has been described above. Three other reported carcinogens were also tested in conditions similar to those used for mustards and found to have no inactivating effect on the transforming principle. These agents were: 20-methylcholanthrene, a saturated solution in $0.1 \mathrm{M}$ citrate buffer and $0.5 \mathrm{~cm}^{3}$ of $0.15 \mathrm{M}$ solution in $\mathrm{CHCl}_{3}$ emulsified in $0.5 \mathrm{~cm}^{3}$ of

- Obtained from Air Reduction. Chemical Co., New York. 
the solution of transforming principle in the same buffer; 4-dimethylaminobenzene, a saturated solution in the same buffer; ethyl carbamate (urethan), $0.75 \mathrm{~m}$ in the same buffer. These results suggest, but by no means prove, that the carcinogens in general can be divided into two classes: those, like ultraviolet and mustards, which exert their effect by reacting directly with DNA, and those which do not react with DNA. Admittedly, many objections could be raised against such conclusions. It could be argued that the reactions of DNA with carcinogenic and carcinostatic agents are of such subtle nature that they cannot be detected even by so sensitive a method as the transforming activity; this point will be discussed further on. It could also be argued that the lack of demonstrable reactions with DNA in vitro does not preclude some reaction in the presence of other cell components in the living system.

As mentioned above, the nitrogen mustards and 1,5-diaminobiuret are reported to have also a carcinostatic action. Several other reported carcinostatic agents (Gellhorn and Hirschberg, 1955) were also tested and found to have no inactivating effect on the transforming principle. These agents were: amethopterin ${ }^{7}$ (saturated; approximately $0.004 \mathrm{M}$ ); $\mathrm{N}$-methyl formamide ${ }^{7}$ (1.4 M); 6-mercaptopurine ${ }^{7}$ (saturated); ethyl carbamate (as mentioned above); 8-azaguanine ${ }^{7}$ (as reported by Zamenhof et al., 1953); 2,6diaminopurine $^{7}$ (saturated, approximately $0.025 \mathrm{M}$ ); di-methylsulfonates of ethylene glycol and of 1,4-dihydroxybutane ${ }^{5}$ (as mentioned above); 2,4-diamino-5-( $3^{\prime}, 4^{\prime}$-dichlorophenyl)-6ethyl-pyrimidine $^{7}$ (saturated); deoxypyridoxine ${ }^{7}$ $(0.4 \mathrm{M})$; colchicine ${ }^{7}$ (0.08 $\left.\mathrm{M}\right)$; netropsin ${ }^{7}$ (amount sufficient to precipitate all DNA which was redissolved after treatment); and azaserine ${ }^{7}$ $(0.25 \mathrm{M})$. As in the case of carcinogenic agents, these results suggest, but by no means prove, that the carcinostatic agents in general may be divided into two classes: (a) those, like mustards and diaminobiuret, which exert their effect by inactivating the DNA of malignant cells, and (b) those which do not react with DNA.

The inability of some strong protein denaturing agents to inactivate the transforming principle

7 Kindly supplied by Drs. A. Gellhorn and E. Hirschberg, College of Physicians and Surgeons, Columbia University, New York. has been reported in the previous paper (Zamenhof et al., 1953). A few others were also tested in conditions similar to those used for mustards and found to have no inactivating effect on the transforming principle. These agents were: urea, $4 \mathrm{M}$; “duponol C" (15 per cent; previously tested in concentration 0.5 per cent, Zamenhof et al., 1953); sodium 2,4-dimethylbenzenesulfonate and sodium 2,5-dimethylbenzenesulfonate, ${ }^{8} 15$ per cent or approximately $0.7 \mathrm{M}$. Urea has been reported to damage calf thymus DNA (Conway and Butler, 1952; Stacey and Alexander, 1954); it is likely that the DNA used in these studies was already somewhat injured since it is known that the injured DNA is less resistant to various agents (Zamenhof et al., 1954). Indeed, urea had no demonstrable effect on the physical properties of DNA of calf thymus isolated by a method similar to that which yielded active transforming principle (Zamenhof et al., 1954), or by another method yielding high molecular weight DNA (Doty and Rice, 1955). The remarkable resistance of the transforming principle to agents which strongly denature protein is again an indication that the proteins are unlikely to form a functional part of the active molecule.

The Unstable Transforming Principle. When the inactivation of the transforming principle by heat (Zamenhof et al., 1953) was studied in function of time at $76 \mathrm{C}$ and $81 \mathrm{C}$, data represented in figure 3 were obtained. The shape of the curves suggests that the reactions involved are not of simple first order reaction like those reported, for instance, for thermal inactivation of bacterial viruses (Pollard and Reaume, 1951). The curves suggest that more than one reaction is involved, such as unstabilization (more horizontal portion) followed by actual inactivation. When nonheated samples and samples heated for $4 \mathrm{hr}$ at $76 \mathrm{C}$ (figure 3 ) were subsequently stored at $6 \mathrm{C}$ for $72 \mathrm{hr}$, the activity of the nonheated sample did not decrease whereas the activity of the sample heated $4 \mathrm{hr}$ decreased by 99 per cent. This may indicate that the surviving molecules are less stable than the average original ones and that the process of unstabilization of remaining active molecules progresses during the inactivation of others. Essentially similar results were obtained in tests of unstabilization at a higher

8 Recently suggested as protein denaturing agent in the procedure for isolation of DNA (Simmons et al., 1952). 


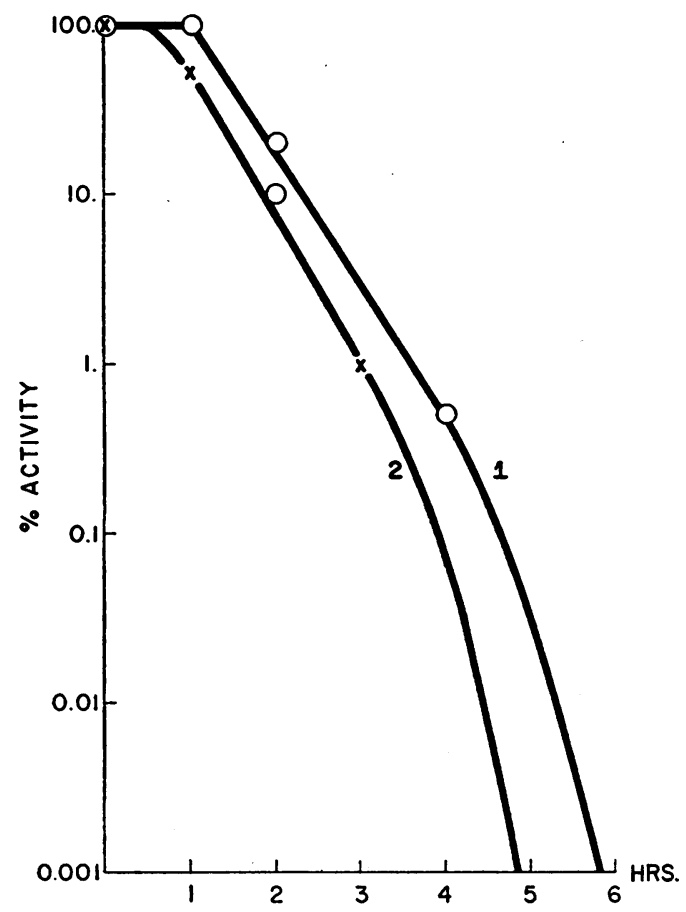

Figure 3. Kinetics of inactivation of the transforming principle by heat. The ordinate as on figure 1 ; the abscissa indicates the duration of heating at $76 \mathrm{C}$ (curve $1, \mathrm{O}$ ) or $81 \mathrm{C}$ (curve $2, \mathrm{X}$ ).

temperature (91.5 C) for a shorter time $(1 \mathrm{hr})$, or in tests of loss of viscosity (Zamenhof et al., 1953) after prolonged heating at $76 \mathrm{C}$.

An unstabilization can also be produced by agents other than heat. Samples of transforming principle, subjected to subinactivating treatment with ultraviolet, nitrogen mustard $(\mathrm{HNl}), \mathrm{H}^{+}$ (but not $\mathrm{OH}^{-}$), dimethyl sulfate, diaminobiuret, or crystalline pancreatic deoxyribonuclease (Zamenhof et al., 1953) were exposed to $76 \mathrm{C}$ for $1 \mathrm{hr}$. The samples lost their remaining activity (table 5), although such heating did not induce any loss of activity of the intact transforming principle.

Unstabilization of DNA prior to inactivation is apparently a general phenomenon induced by mutagenic and other agents. It was of interest to investigate whether such an unstable state is hereditary. To this end, the transforming principle was heated for $1 \mathrm{hr}$ at $91.5 \mathrm{C}$ or treated by $7 \times 10^{-8}$ nitrogen mustard ( $\mathrm{HNl}$ ) as described in the previous sections. Two aliquots of the samples were then used for the measurement of the remaining activity and the loss of stability to heat $(76 \mathrm{C}, 1 \mathrm{hr})$; the remaining portions of the samples were used for another transformation experiment. One cell so transformed yielded a colony from which broth suspensions were made for the seeding of 100 Leventhal agar plates; the yield from the latter was used for the usual preparation of the transforming principle. Results in table 6 show that no heat instability could be demonstrated in the reproduced, originally heatunstable, transforming principle. This may mean that the original injury (unstabilization) was repaired during reproduction; however, it must be pointed out that a small percentage of molecules reproducing as unstable would not be detectable in this method. Obviously, more evidence is needed and the work on this important subject is being continued.

It has been suggested repeatedly (Auerbach et al., 1947; Witkin, 1951; McElroy and Swanson, 1951; Kaplan, 1952; Demerec, 1955) that under the influence of the mutagenic agents the "gene" in the living cell may undergo unstabilization, and that such hypothetical unstable gene either returns to a normal state or changes into a mutated gene presumably at time of reproduction; the mutagen may not be necessary for this secondary change ("delayed mutation"). Thus,

\section{TABLE 5}

\section{Unstabilization of the transforming principle} by various agents

\begin{tabular}{|c|c|c|c|c|}
\hline \multirow[b]{2}{*}{ Agent } & \multirow{2}{*}{$\begin{array}{c}\text { Re- } \\
\text { ported } \\
\text { Muta- } \\
\text { genicity }\end{array}$} & \multirow{2}{*}{$\begin{array}{c}\text { Dose or } \\
\text { Concentration }\end{array}$} & \multicolumn{2}{|c|}{$\begin{array}{l}\text { Activity, Per Cent } \\
\text { of Original }\end{array}$} \\
\hline & & & $\begin{array}{l}\text { Before } \\
\text { heating }\end{array}$ & $\begin{array}{c}\text { After } \\
\text { heating } \\
(76 \mathrm{C}, \\
1 \text { hr) }\end{array}$ \\
\hline $\begin{array}{l}\text { Untreated } \\
\text { control .. }\end{array}$ & 一 & - & 100 & 100 \\
\hline Ultraviolet. & + & $\begin{array}{l}410 \mathrm{ergs} / \mathrm{mm}^{2} \\
615 \mathrm{ergs} / \mathrm{mm}^{2}\end{array}$ & $\begin{array}{l}2 \\
0.1\end{array}$ & $\begin{array}{l}0.02 \\
0\end{array}$ \\
\hline HN1. & + & $2.2 \times \cdot 10^{-3} \mathrm{M}^{*}$ & 60 & $\mathbf{0}$ \\
\hline $\begin{array}{l}\mathrm{H}^{+} \ldots \ldots . . \\
\text { Dimethyl }\end{array}$ & $?$ & $10^{-3}$ м $\dagger$ & 0.2 & 0 \\
\hline $\begin{array}{c}\text { sulfate. ... } \\
\text { Diamino- }\end{array}$ & + & $10^{-8} \mathrm{M}^{*}$ & 0.1 & $\mathbf{0}$ \\
\hline biuret.... & + & $4 \times 10^{-3} \mathrm{M}^{*}$ & 5 & 0 \\
\hline DNAase.... & $?$ & $10^{-12} \mathrm{M} \ddagger$ & $\begin{array}{l}20 \\
0.2\end{array}$ & $\begin{array}{l}2 \\
0\end{array}$ \\
\hline
\end{tabular}

* $6 \mathrm{hr}, 23 \mathrm{C}$; precipitated, washed, redissolved. $\dagger 2 \mathrm{hr}, 23 \mathrm{C}$; precipitated, washed, redissolved. $\ddagger 30 \mathrm{C}$; precipitated, washed, redissolved. See Zamenhof et al. (1953) for details. 
TABLE 6

Reproduction of unstable transforming principle

\begin{tabular}{|c|c|c|c|c|c|}
\hline \multirow{3}{*}{$\begin{array}{l}\text { Unstabi- } \\
\text { lizing agent }\end{array}$} & \multirow{3}{*}{ Conditions } & \multirow{2}{*}{\multicolumn{2}{|c|}{$\begin{array}{c}\begin{array}{c}\text { Before } \\
\text { Reproduction }\end{array} \\
\begin{array}{c}\text { Activity, } \\
\text { Per cent of } \\
\text { original }\end{array}\end{array}$}} & \multirow{2}{*}{\multicolumn{2}{|c|}{$\frac{\begin{array}{c}\text { After } \\
\text { Reproduction }\end{array}}{\underbrace{}_{\begin{array}{c}\text { Activity, } \\
\text { Per cent of } \\
\text { original }\end{array}}}$}} \\
\hline & & & & & \\
\hline & & $\begin{array}{l}\text { Before } \\
\text { heating }\end{array}$ & $\begin{array}{c}\text { After } \\
\text { heating, } \\
1 \mathrm{hr}, \\
76 \mathrm{C}\end{array}$ & $\begin{array}{c}\text { Before } \\
\text { heating }\end{array}$ & \begin{tabular}{|} 
After \\
heating, \\
$1 \mathbf{h r}$, \\
$76 \mathrm{C}$
\end{tabular} \\
\hline Heat & $\begin{array}{c}91.5 \mathrm{C} \\
1 \mathrm{hr}\end{array}$ & 2 & 0.1 & 100 & 100 \\
\hline $\begin{array}{l}\text { Nitrogen } \\
\text { mustard } \\
\text { HN1 }\end{array}$ & $\begin{array}{c}7 \times 10^{-8} \mathrm{M} \\
6 \mathrm{hrs} \\
23 \mathrm{C}\end{array}$ & 1 & 0 & 100 & 100 \\
\hline
\end{tabular}

the process of unstabilization may be important for the subsequent phenomenon of mutation by determining the place on the molecule (the "injury") where the faulty reproduction (the mutation?) is most likely to occur. Although some of these hypotheses are still purely speculative, attention can be drawn to the fact that the mutagenic agents cause both unstabilization of the gene in the living cell and the unstabilization of heredity determinants in the form of transforming principle (DNA) in vitro. This suggests that the unstabilization of the "gene" in the cell is a chemical process and that the genic material undergoing unstabilization in vivo is indeed DNA. The chemical nature of the process of DNA unstabilization is of course not yet known; it need not be the same for various unstabilizing agents. From what is known about the action of these agents on DNA-change of shape of the molecule (Zamenhof et al., 1953), depurination, alkylation-one could suggest as a working hypothesis that the unstabilization is a breakage of a few hydrogen bonds not yet sufficient for immediate total inactivation, but sufficient for making the molecule vulnerable to other detrimental influences such as heat or even to storage in the cold. The "multi-hit" type of curve of inactivation of the transforming principle by ultraviolet irradiation (figure 1) suggests that single hits may not carry sufficient energy for complete inactivation but may be sufficient for unstabilization: indeed, the data in table 5 suggest that practically every molecule surviving $400 \mathrm{ergs} / \mathrm{mm}^{2}$ must have received at least one hit, because although still active, these molecules subsequently proved unstable following exposure to higher temperatures.

\section{DISCUSSION}

One purpose of this study was the demonstration of several parallelisms between mutagenicity and activity of several mutagenic agents against the transforming principle. Admittedly, the demonstrable effect here was inactivation rather than mutation in vitro; however, striking similarities between the lethal and the mutagenic effect of radiation have suggested that the two processes differ in intensity rather than in chemical nature (McElroy, 1952).

In several cases the chemical nature of the reaction between a mutagen and the transforming principle can be determined. Such a study reveals the diversity of reactions characteristic of diverse mutagenic agents; yet they all seem to prime a common biological phenomenon (mutation). This suggests that the mutations themselves are of diverse chemical nature and that the direct effect of the mutagenic agents is another process, preceding true mutation. A further purpose of this work was to provide support for the latter premises: it has been found that the direct effect of mutagens in vitro on the transforming principle prior to inactivation is the change of the latter into an unstable form.

\section{ACKNOWLEDGMENT}

The authors are indebted to Drs. J. W. Fertig and A. P. Berger for advice in the statistical analysis.

\section{APPENDIX}

Statistical interpretation. The method used for testing the transforming activity consists essentially in adding the transforming principle in various dilutions to the cell suspension containing cells sensitive to transformation, and testing for the appearance of at least one transformed cell. Each such experiment is performed in duplicate and the activity of the transforming principle is calculated from the highest dilution which still gives transformation in both samples of the pair.

To test the inactivation of the transforming principle by an agent, a control pair without this agent and several experimental pairs with the agent in various concentrations are tested as described before. Each such complete test is repeated 2 to 3 times. If the agent used causes a decrease of activity, it is of interest to investigate the statistical significance of such finding. For this purpose it is first necessary to study the error inherent in the method used. 
Standard deviation in a pair of two samples has been calculated from the log of activities of each sample in 33 control and 39 experimental (partial inactivation) pairs. The value so obtained was $\sigma_{\mathrm{d}}=0.247$. If a difference between the control and the experimental pair in this case is to be considered significant $(P<0.01)$, the activity of the experimental sample (geometric mean of two samples in a pair) should be at least 4.35 times lower than the control. The analysis of the tests in which only the lower value of the two is taken, gives in this particular case similar results. Thus, an activity equal to 50 per cent of the original does not represent a significant decrease, whereas an activity equal to 20 per cent of the original does.

This analysis should always be taken into consideration when interpreting the results in this paper.

\section{SUMMARY}

The action of mutagens on the activity of the transforming principle of Haemophilus influenzae has been studied. The majority of strong mutagens, even in minute doses, inactivate the transforming principle; this suggests that DNA is the site of action of these mutagens.

The chemical and physical nature of the reactions between certain mutagens and the transforming principle has been analyzed. An unstabilization of the transforming principle in vitro following exposure to subinactivating concentrations of mutagens has been demonstrated and the possible relation between this phenomenon and the previously suggested unstabilization of genes prior to mutation has been discussed.

\section{REFERENCES}

Alexander, P. 1952 Interference with the formation of a nucleoprotein complex by radiomimetic compounds. Nature, 169, 226227.

Auerbach, C. And Robson, J. M. 1946 Chemical production of mutations. Nature, 157, 302.

Aunrbach, C., Robson, J. M., and Carr, J. G. 1947 The chemical production of mutations. Science, 105, 243-247.

Bergel, F. ANd Stock, J. A. 1953 Cytotoxic alpha amino acids and peptides. Brit. Empire Cancer Campaign Ann. Rep., 31, 6-7.
Brachet, J. 1939 Quelques propriétés chimiques de la vésicule germinative isolée. Arch. Exptl. Zellforsch., 22, 541.

Brit. Empire Cancer Campaign Ann. Rep., 1952, $30,25$.

Cancer Chemotherapy and Studies on the Mechanism of Action of Anticancer Agents. 1953 Observations on the anticancer activity of 1,5-diaminobiuret. Progress Report, Biological Lab. Southern Research Inst., C1-C5.

Clark, J. B. 1953 (Publ. 1955) The mutagenic action of various chemicals on Micrococcus aureus. Proc. Oklahoma Acad. Sci., 34, 114117.

Conway, B. E. and Butler, J. A. V. 1952 The action of denaturing agents on deoxyribonucleic acid. J. Chem. Soc., 1952, 3075-3082.

Davison, P. F., Conway, B. E., and Butler, J. A. V. 1954 The nucleoprotein complex of the cell nucleus and its reactions. Progress in Biophysics, 4, 148-194.

Demerec, M. 1951 Induction of mutations in Escherichia coli by manganous chloride. Science, 113, 473-474.

Demerec, M. 1953 Reaction of genes of Escherichia coli to certain mutagens. Symposia Soc. Exptl. Biol., 7, 43-54.

Demerec, M. 1955 What is a gene?-twenty years later. Amer Naturalist, 89, 5-20.

Demerec, M., Moser, H., Hemmerly, J., Bloomstrand, I., Demerec, Z. E., Fitzgerald, P. L., Glover, S. W., Hanson, J. F., Nielsen, F. J. ANd YURA, T. 1954 Bacterial Genetics -I. Carnegiê Inst. Wash., Yearbook, 53, 225241.

Demerec, M., Witkin, E. M., Beckhorn, E. J., Visconti, N., Flint, J., Cahn, E., Coon, R. C., Dollinger, E. J., Powell, B. AND Schwarz, M. 1951 Bacterial Genetics, Carnegie Inst. Wash. Yearbook, 60, 181-195.

Doty, P. AND RICE, S. A. 1955 The denaturation of desoxypentose nucleic acids. Biochim. et Biophys. Acta, 16, 446-448.

Gellhorn, A. and Hirschberg, E., Editors, 1955 Investigation of diverse systems for cancer chemotherapy screening. Cancer Research, suppl. 3, 1-125.

Gresham, T. L., Jansen, J. E., Shaver, F. W., Bankert, R. A. and Fiedorek, F. T. 1951 $\beta$-Propiolactone. XI. Reaction with ammonia and amines. J. Am. Chem. Soc., 73, 3168-3171.

HemmerLY, J. H. 1954 Mutagenic action of possible anti-tumor compounds on $E$. coli. $\mathrm{Mi}$ crobial Genetics Bull., No. 10, 15.

HERRIOTT, R. M. 1948 Inactivation of viruses and cells by mustard gas. J. Gen. Physiol., 32, 221-239. 
HILl, R. F. AND Rossi, H. H. 1952 Absence of photoreactivation in $\mathrm{Tl}$ bacteriophage irradiated with ultraviolet in the dry state. Science, 116, 424-425.

Kaplan, R. W. 1952 Auslösung von Farbsektorund anderen Mutationen bei Bacterium prodigiosum durch monochromatisches Ultraviolett verschiedener Wellenlängen. $\mathbf{Z}$. Naturforsch., 7b, 291-304.

Kelner, A. 1949 Effect of visible light on the recovery of Streptomyces griseus conidia from ultraviolet irradiation injury. Proc. Natl. Acad. Sci., 35, 73-79.

KOFFLER, H. AND MARKGRT, I. L. 1951 Effect of photodynamic action on the viscosity of desoxyribonucleic acid. Proc. Soc. Exptl. Biol. Med., 76, 90-92.

Kolmark, G. and Giles, N. H. 1953 Studies on chemical mutagens using the Neurospora back-mutation test. Records Genetics Soc. Am., 22, 84.

Limperos, G. and Mosher, W. A. 1950 Roentgen irradiation of desoxyribonucleic acid. I. Mechanism of the action of irradiation in aqueous solution. Am. J. Roentgenol. Radium Therapy, 63, 681-690.

Loveless, A. 1951 Qualitative aspects of the chemistry and biology of radiomimetic (mutagenic) substances. Nature, 167, 338342.

LuRIA, S. E. 1953 General Virology. J. Wiley and Sons, New York.

McCarty, M. 1945 Reversible inactivation of the substance inducing transformation of pneumococcal types. J. Exptl. Med., 81, 501514.

McElroy, W. D. 1952 Evidence for the occurrence of intermediates during mutation. Science, 115, 623-626.

McElroy, W. D. and Swanson, C. P. 1951 The theory of rate processes and gene mutation. Quart. Rev. Biol., 26, 348-363.

Philips, F. S. 1950 Recent contributions to the pharmacology of bis(2-haloethyl)amines and sulfides. J. Pharmacol. Exptl. Therap., 99, II 281-323.

Pollard, E. ANd Reaume, M. 1951 Thermal inactivation of bacterial viruses. Arch. Biochem. and Biophys., 32, 278-287.
RAPOPORT, I. A. 1947 Inheritance changes taking place under the influence of diethyl sulfate and dimethyl sulfate. Dok. Vsesoyuz Akad. Sel'sko-khoz. Nauk im. V.I. Lenina, 12, 12-15; (Chem. Abstr. 1948, 42, 3790).

Ross, W. C. J. 1953 The chemistry of cytotoxic alkylating agents. Advances in Cancer Research, 1, 397-449.

Ross, W. C. J. 1954 The correlation of chemical structure with cytotoxic activity in the nitrogen mustards. Acta Unio Intern. contra Cancrum, 10, 159-160.

Simmons, N. S., Charos, S., and Orbach, H. K. 1952 Ten-hour preparation of pure, highly polymerized thymus nucleic acid. Federation Proc., 11, 390.

Stacey, K. A. and Alexander, P. 1954 Evidence for a two-molecule aggregate for DNA solution: Trans. Faraday Soc., 50, 303.

TonUTT, E. 1938 Ergebnisse histochemischer Vitamin C-Untersuchungen. Protoplasma, 31, 151-158.

WItKIN, E. M. 1951 Nuclear segregation and the delayed appearance of induced mutants in Escherichia coli. Cold Spring Harbor Symposia Quant. Biol., 16, 357-372.

ZAMenhoF, S. 1954 Studies on the chemistry of mutation. Science, 120, 791.

ZamenhoF, S. 1956 Biology and biophysical properties of transforming principles. Progress in Biophysics, 6, 85-119.

Zamenhof, S., Alexander, H. E., and Leidy, G. 1953 Studies on the chemistry of the transforming activity. I. Resistance to physical and chemical factors. J. Exptl. Med., 98, 373-397.

Zamenhof, S., Griboff, G., and Marullo, N. 1954 Studies on the resistance of desoxyribonucleic acids to physical and chemical factors. Biochim. et Biophys. Acta, 13, 459-470.

Zamenhof, S., Leidy, G., ANd HahN, E. 1954 Unstability of the transforming principle induced by mutagenic agents. Records Genetics Soc. Am., 23, 75.

ZAMenhof, S. Leidy, G., ANd Reiner, B. 1954 The action of some mutagenic, carcinogenic and carcinostatic agents on DNA having transforming activity. Proc. Am. Assoc. Cancer Research, 1, 53. 